\title{
Vermicomposting of Solid Waste Using Local and Exotic Earthworms - A Comparative Study
}

\author{
AMIT KRISHAN $^{1}$, M. ARTHANAREESWARI ${ }^{2 *}$ and P. KAMARAJ ${ }^{2}$ \\ Department of Civil Engineering, IEC Group of Institutions, Greater Noida-201310, India \\ Department of Chemistry, SRM University, Kattankulathur-603203, Tamilnadu, India \\ arthanareeswari@gmail.com
}

Received 19 November 2013 / Accepted 29 December 2013

\begin{abstract}
The aim of this study was to assess the decomposition efficiency of earthworms, local (L.mauritii) as well as exotic (Eisenia foetida) in vermicomposting of garden litter in SRM University campus, Tamilnadu, India. The vermicompost produced through vermicomposting of garden litter mixed with cow dung in the ratio of 3:1 by using local and exotic earthworms (Eisenia foetida) were rich in ammoniacal nitrogen, nitrate nitrogen, available phosphorus, total potassium \& TKN and there was a reduction in total organic carbon and carbon to nitrogen ratio. The study reveals that the decomposition efficiency of exotic earthworms is better when compared to local earth worms.
\end{abstract}

Keywords: Garden litter, Vermicompost, Local, Exotic earthworms

\section{Introduction}

The problem of solid waste management has been increased due to the rapid increase of population, intensive agriculture and industrialization. Large quantities of organic waste are produced and they pose major environmental (offensive odours, contamination of ground water and soil) and disposal problems world wide ${ }^{1}$. Effective disposal of different types of waste has become important to maintain healthy environment ${ }^{2}$. To solve this problem scientists are in search of better management alternative, which should be eco-friendly, cheap and rapid particularly suited to Indian conditions.

Vermicomposting has become an appropriate alternative for the safe, hygienic and cost effective disposal of organic solid wastes ${ }^{3-6}$. Earth worms decompose organic waste leading to the production of compost which is high in nutrients content compared to the raw waste material from which it is produced ${ }^{7}$. This compost will be an alternate for chemical fertilizers which are used to improve the growth and yield of plants.

In the process of vermicomposting of organic solid wastes the action of earthworms are physio-biochemical. Substrate aeration, mixing as well as grinding include physical processes while the biochemical process is influenced by microbial decomposition of substrate in the intestine of earthworms ${ }^{3}$. Vermicomposting of organic wastes accelerates organic matter stabilization ${ }^{8,9}$ and gives chelating and phytohormonal elements ${ }^{10}$ which have 
a high content of microbial matter and stabilized humic substances. Exotic species, like Eudrilus euginae ${ }^{11}$, Pariyonyx excavatus ${ }^{12}$ and Eisenia fetida ${ }^{13}$ are employed for vermicomposting in India next to local species L.mauritii ${ }^{14,15}$ which is widely distributed. Considering all the above facts, the present study assessed the potential of Eisenia fetida and L.mauritii in composting the garden litter.

\section{Experimental}

A rectangular pit was excavated on ground of volume $6.75 \mathrm{ft}^{3}(3 \mathrm{ft} \times 1.5 \mathrm{ft} \times 1.5 \mathrm{ft})$ for performing the experiment (Figure 1). The pit was earthen in origin, a geo-membrane of thick plastic (almost $50 \mathrm{~mm}$ ) was used for covering the sides of the rectangle and the upper surface was open for the maintenance of vermibed. The pit was excavated in shady place because earthworms are nocturnal in nature. Jute was used to cover the pit.

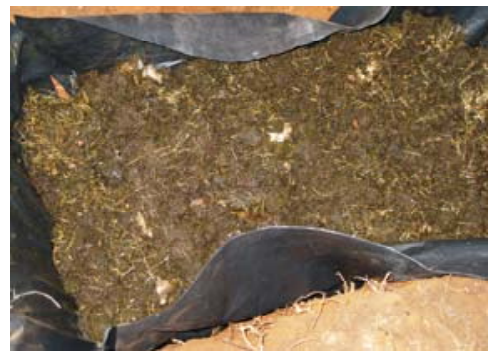

Figure 1. Vermicompost pit loaded with the raw material and earthworms

\section{Collection of earth worms}

For this study the local earthworms (L.mauritii) collected from Chennai Agriculture Research Institute, Kattankulathur, Chennai and exotic species (Eisenia foetida) from P.G. Department of Environmental Sciences, A.N. College, Patna, Bihar were used.

\section{Raw materials used in vermicomposting}

1 Part cow dung and 3 parts of garden litter were the raw materials used for this investigation. Jute was used to cover the pit. The garden litter was collected from SRM University, Kattankulathur campus and cow dung was collected from Potheri village near by SRM University, Kattankulathur, India

\section{Start-up process}

The start-up process began with culture of earthworms in vermibed. Cow dung was used as culturing material for local species and Eisenia foetida. Earthen pots of size $30 \mathrm{~cm}$ height and $30 \mathrm{~cm}$ diameter with a hole at the bottom were filled with $2 \mathrm{~kg}$ of cow dung which was 3-4 days old, as fresh cow dung contains lot of bacteria which inhibit its growth. A layer of cow dung of thickness $1 / 2 \mathrm{ft}$. was spread over the bottom of the floor of the pots. Earthworms (about 100) were slowly released in pots and a thick layer of cow dung was spread to cover the earthworms. Temperature and moisture was measured and maintained at $30 \pm 3{ }^{\circ} \mathrm{C}$ and $50 \%$ respectively through sprinkling of water. The upper surface of vermibed was covered by Jute. Jute prevents temperature fluctuation and moisture fluctuation in between environment and vermibed and also works as a stabilizer. The maximum duration of culturing of earthworms was about 30 days, during which the population of earthworm increased to about 2000 in the case of Eisenia foetida and about 1000 in the case of local earthworms. It was sufficient to start the experiment. 


\section{Sampling and Analysis}

The pits were loaded with $20 \mathrm{~kg}$ of definite proportion of crushed garden litter and cow dung in 3:1 ratio. In each pit equal no (1000) of earthworms were introduced. The duration of the study was 90 days. A composite sample was taken before the introduction of earth worms and analyzed for raw material characteristics. Other composite samples of degraded material were taken and analyzed at 30 days interval as prescribed in the manual for compost issued by Central Pollution Control Board, New Delhi and Standard Methods ${ }^{11}$. All the determinations were carried out in triplicate. All the reported data are the arithmetic means of three replicates.

\section{Results and Discussion}

The $\mathrm{pH}$, total organic carbon, ammoniacal nitrogen, total Kjeldahl nitrogen and nitrate nitrogen, $\mathrm{C}$ : $\mathrm{N}$ ratio, available phosphate and total potassium were analyzed in each sample of vermicompost and also for the raw material before vermicomposting started. The result is presented in Table $1 \& 2$.

Table 1. Composition of raw material \& vermicompost (Local Species) mixture

\begin{tabular}{|c|c|c|c|c|c|c|c|c|c|}
\hline 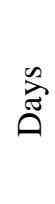 & $\stackrel{T}{a}$ & 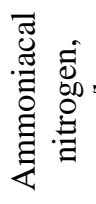 & 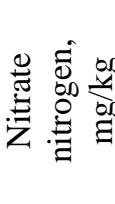 & 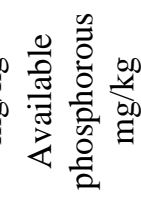 & 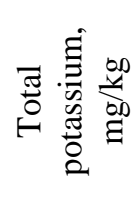 & 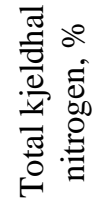 & 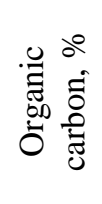 & 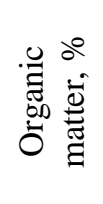 & 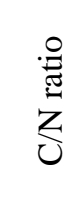 \\
\hline 0 & 7.36 & 392 & 810 & 399.75 & 7.0 & 0.66 & 16.63 & 28.67 & 25.20 \\
\hline 30 & 7.23 & 516 & 836 & 610.90 & 8.8 & 0.72 & 14.97 & 25.80 & 20.79 \\
\hline 60 & 6.97 & 618 & 856 & 764.60 & 10.6 & 0.79 & 13.20 & 22.75 & 16.70 \\
\hline 90 & 6.94 & 721 & 928 & 856.70 & 11.0 & 0.85 & 11.76 & 20.27 & 13.83 \\
\hline
\end{tabular}

Table 2. Composition of raw material \& vermicompost (Exotic Species) mixture

\begin{tabular}{|c|c|c|c|c|c|c|c|c|c|}
\hline$\sum_{\overrightarrow{0}}^{\infty}$ & 涪 & 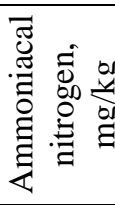 & 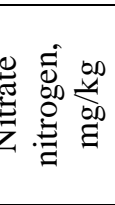 & 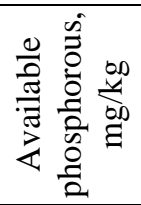 & 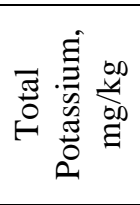 & 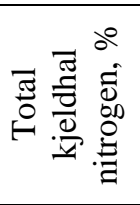 & 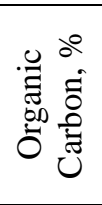 & 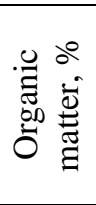 & 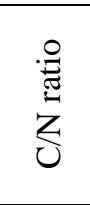 \\
\hline 0 & 8.10 & 388 & 796 & 512.5 & 7.4 & 0.68 & 16.50 & 28.44 & 24.60 \\
\hline 30 & 7.50 & 540 & 832 & 910.2 & 13.0 & 0.77 & 15.61 & 26.91 & 20.27 \\
\hline 60 & 7.20 & 818 & 842 & 1004.5 & 14.6 & 0.92 & 10.66 & 18.37 & 11.59 \\
\hline 90 & 6.98 & 975 & 920 & 1125.6 & 15.6 & 0.98 & 8.32 & 14.34 & 8.48 \\
\hline
\end{tabular}

Impact of vermicomposting on $\mathrm{pH}$

The analysis report (Figure 2) shows that the $\mathrm{pH}$ of the final vermicompost was $6.94 \& 6.98$ for local and epigeic earthworms (Eisenia foetida) respectively. The lower $\mathrm{pH}$ recorded in the final products might have been due to the production of $\mathrm{CO}_{2}$ and organic acids by microbial metabolism during decomposition of the substrate (cow dung: garden litter; 1:3 ratio) in the feed mixture ${ }^{14-17}$. Similar results on vermicomposting of cattle manure, fruit and vegetable wastes have been reported ${ }^{18,19}$. The decline in $\mathrm{pH}$ was also might be due to the higher mineralization of nitrogen and phosphorous into nitrate/ nitrates and orthophosphate ${ }^{15}$. Decrease in $\mathrm{pH}$ is an important factor in nitrogen retention as this element is lost as volatile ammonia at higher $\mathrm{pH}^{20}$. 


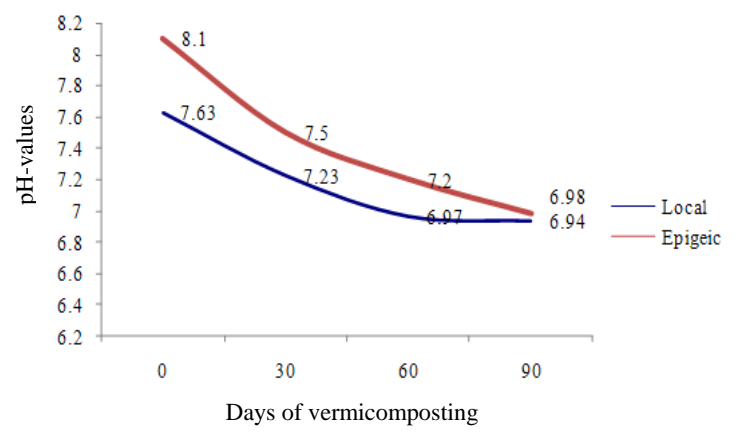

Figure 2. Variation of $\mathrm{pH}$ during vermicomposting

\section{Nutritional value of vermicompost}

After the analysis of vermicompost of both species it was observed that the exotic species has the highest potential to convert the raw material into valuable nutritional product. After 90 days, E.fetida produced a vermicompost which has 151\%, $120 \%$ and $110 \%$ increase in ammoniacal nitrogen, available phosphorous and total potassium respectively than the raw material used. The significant increase in the ammoniacal nitrogen is probably due to mineralization of the organic matter. The increase in available phosphorous is due to the passage of ingested material through earthworms and also due to the stimulation of microbial flora $^{21}$. The microbial flora also increases the total potassium in the final product. Micro organisms in the feed mixture produce acids which converts the insoluble potassium into soluble on $\mathrm{e}^{22}$. In contrast L.mauritii produced a vermicompost with $84 \%, 114 \%$ and $57 \%$ increase in ammoniacal nitrogen, available phosphorous and total potassium respectively than the raw material used. Nitrate nitrogen increased to $15.6 \%$ and $14.6 \%$ in the final vermicomposts of exotic and local species respectively. Earth worms enhance nitrogen mineralization and involve more in the nitrogen transformations in manure so that the mineral nitrogen may be retained in the nitrate form ${ }^{23}$. The enhancement of nitrogen content may be due to loss of organic carbon ${ }^{24}$. Variation in nutritional values have been shown in Figures 3-7.

\section{Organic carbon and $\mathrm{C} / \mathrm{N}$ ratio}

The study revealed that the organic carbon of vermicompost using local and exotic earthworms is decreased. The maximum reduction (2-fold) was observed in compost using exotic species in comparison to the vermicompost of local species (1.4-fold). The reduction of total organic carbon observed with exotic species is higher when compared to institutional (1.7fold), textile industrial wastes (sludge,1.5-fold and fibre,1.68-fold) ${ }^{22}$ and paper mill and dairy sludge $(1.2-1.7-\text { fold })^{23}$. The organic carbon is lost as $\mathrm{CO}_{2}$ during mineralization of organic matter. Also the $\mathrm{C} / \mathrm{N}$ ratio of the vermicompost using exotic earthworms decreased (2.9-fold) maximum when compared to local earth worms (1.8- fold). The significant decrease in the $\mathrm{C} / \mathrm{N}$ ratio of the vermicompost obtained using exotic earthworms indicates the enhanced organic matter decomposition in the presence of them. It has been shown in Figure 8.

The results demonstrated vermicomposting as an alternative technology for the management of biodegradable organic waste. The compost produced by vermicomposting of cow dung and garden litter (1:3) for 90 days using local and exotic earthworms (Eisenia foetida) were rich in ammonical nitrogen, nitrate nitrogen, available phosphorus, total potassium and TKN and there was reduction in total organic carbon and carbon to nitrogen ratio. The data reveals that the exotic earthworms are superior in performance over local earthworms. 

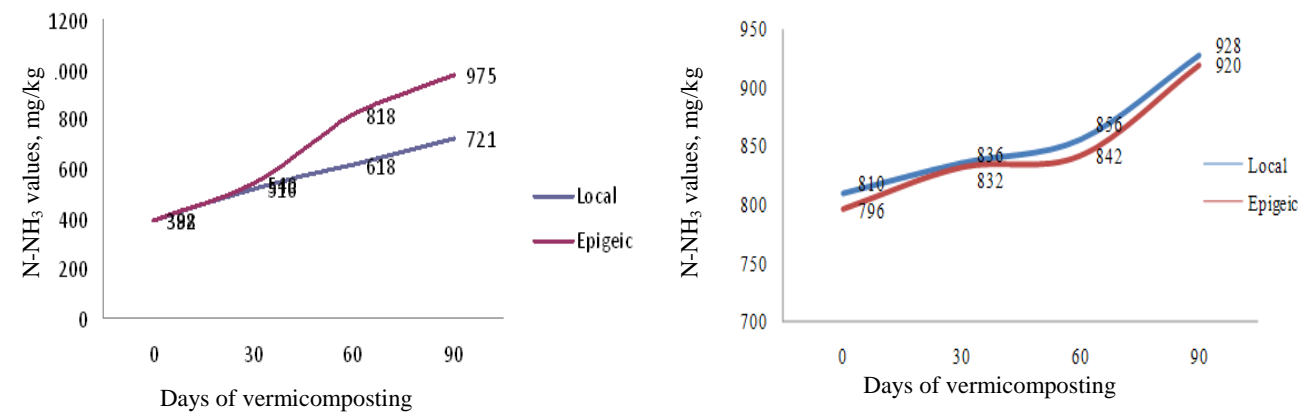

Figure 3. Variation of ammoniacal nitrogen in vermicomposting

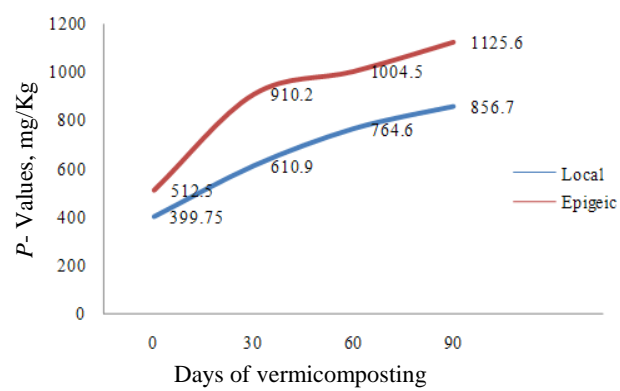

Figure 4. Variation of Nitrate Nitrogen in Vermicomposting

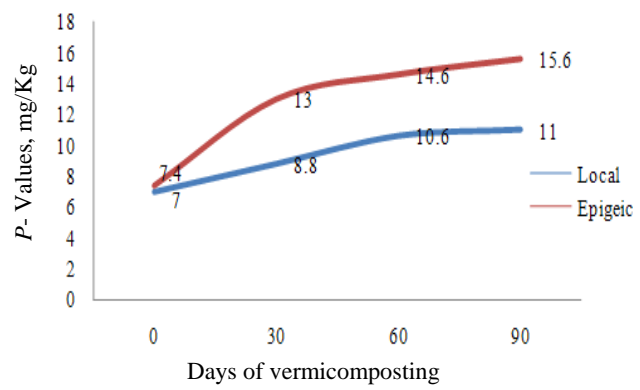

Figure 5. Variation of available phosphorous in vermicomposting

Figure 6. Variation of total potassium in Vermicomposting
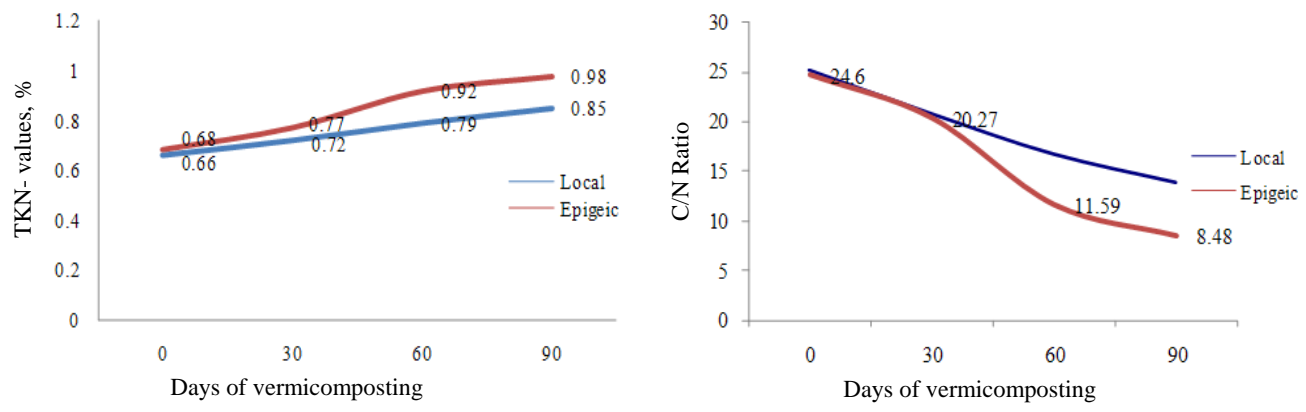

Figure 7. Variation of TKN in vermicomposting

Figure 8. Variation of $\mathrm{C} / \mathrm{N}$ ratio in Vermicomposting

\section{Conclusion}

$>$ Analysis of vermicompost indicates that it is a better organic manure on the basis of nutrient contents.

$>$ Experimental data reveals that vermicomposting is a good method for conversion of garden litter to value added material.

$>\quad$ On the basis of chemical analysis, the observations indicated that Eisenia foetida is superior in performance over local earthworms in vermicomposting of garden litter.

> When compared to institutional, textile industrial waste and paper mill and dairy sludge, the compost produced from garden litter using the exotic earth worms is of superior quality. 


\section{References}

1. Edwards C A and Bater J E, Soil Biol Biochem., 1992, 24(12), 1683-1689; DOI:10.1016/0038-0717(92)90170-3

2. Senapati B K and Julka J M, Selection of suitable vermicomposting species under Indian condition. In: Earthworm Resources and Vermiculture. Zoological Survey of Indian, Calcutta, 1993, 113-115.

3. Hand P, Hayes W A, Frankland J C and Satchell J E, Earthworm Waste Environl Manage., 1988, 49-63.

4. Raymond C L, Jr Martein J H and Neuhauser E F, Stabilization of liquid municipal sludge using earthworms. In: Earthworms in Waste and in Environment Management. SPB Academic Publishing, The Netherlands, 1988, 95-110.

5. Harris R C, Knox K and Walker N, Strategies for the Development of Sustainable Land Fill Design. In: IWM Proceeding, 1990, 26-29.

6. Logsdson G, Worldwide Progress in Vermicomposting, Biocycle, 1994, 35(10), 63-65.

7. Buchanam M A, Rusell E and Block S D, Chemical Characterization and Nitrogen Mineralization Potentials of Vermicompost Derived from Differing Organic Waste. In: Edwards C A, Neuhauser E F, (Eds.), Earthworms in Environmental and Waste Management. SPB Academic Publishing, The Netherlands, 1988, 231-240.

8. Neuhauser E F, Loehr R C and Malecki M R, The potential of earthworms for managing sewage sludge. In: Ewards C A and Nauhauser E F, (Eds.), Earthworms in Waste and Environmental Management. SPB Academic Publishing, The Hague, 1998, 9-20.

9. Fredericksion J, Butt K R, Morris R M and Danial C, Soil Biol Biochem., 1997, 29(3-4), 725-730; DOI:10.1016/S0038-0717(96)00025-9

10. Tomati U, Galli E, Pasetti L and Volterra E, Waste Manage Res., 1995, 13(5), 509-518; DOI:10.1016/S0734-242X(05)80031-X

11. Ashok K C, State of Art Report on Vermicompositng in India. Council for Advancement of people action and Rural Technology (CPART), New Delhi, 1994, 60.

12. Kale R D, Bano K and Krishnamoorthy R V, Pedobiologia, 1982, 23, 419-425.

13. Hartenstein R and Hartenstein F, J Environ Qual., 1981, 10, 377-381; DOI:10.2134/jeq1981.00472425001000030027x

14. APHA, Standard Methods for the Examination of Water and Wastewater, $21^{\text {st }}$ Ed., American Public Health Association, Washington, DC, 2005.

15. Kaviraj and Sharma S, Bioresour Technol., 2003, 90(2), 169-173; DOI:10.1016/S0960-8524(03)00123-8

16. Albanell E, Plaixats J and Cabrero T, Biol Fert Soil., 1988, 6(3), 266-269.

17. Chan P L S and Griffiths D A, Biol Waste., 1988, 24(1), 57-69; DOI:10.1016/0269-7483(88)90027-4

18. Haimi J and Hutha V, Biol Fert Soil., 1986, 2(1), 23-27; DOI:10.1007/BF00638957

19. Edwards C A and Lofty J R, Biology of Earthworms. Chapman and Hall, London 1972.

20. Mitchell A, Soil Biol Biochem., 1997, 29(3-4), 763-766.

21. Mansell G P, Syers J K and Gregg P E H, Soil Biol Biochem., 1981, 13(2), 163-167; DOI:10.1016/0038-0717(81)90013-4

22. Atiyeh R M, Dominguez J, Subler S and Edwards C A, Pedobiologia, 2000, 44(6),709-724; DOI:10.1078/S0031-4056(04)70084-0

23. Viel M, Sayag D and Andre L, Elsevier Appl Sci Essex., 1987, 230-237.

24. Payal Garg, Asha Gupta and Santosh Satya V, Bioresour Technol., 2006, 97(3), 391-395.

25. Elvira C, Sampedro L, Benitez E and Nogales R, Bioresour Technol., 1998, 63(3), 205-211. 